\title{
Tingkat Pengangguran Akibat Covid-19 di Provinsi Nusa Tenggara Barat
}

\author{
Ikang Murapi, Dewa Ayu Oki Astarini, I Nyoman Subudiartha \\ Akuntansi Universitas Bumigora Mataram \\ ikangmurapi11@universitasbumigora.ac.id, Oki.astarini22@gmail.com
}

\begin{abstract}
Abstrak:
Penelitian ini bertujuan untuk mengetahui kenaikan tingkat pengangguran akibat Covid 19 di Provinsi Nusa Tenggara Barat. Jenis Penelitian yang dipergunakan adalah metode deksriptif dengan menggunakan data sekunder yang dianalisis menggunakan analisis pertumbuhan pada tingkat pengangguran. Hasil penelitian menunjukkan menunjukkan bahwa dari 3,82 juta penduduk usia kerja, terdapat 455,56 ribu orang (11,93 persen) yang terdampak Covid-19. Sebagian besar penduduk usia kerja yang terdampak Covid-19 mengalami pengurangan jam kerja, yaitu sebanyak 378,85 ribu orang (83,16 persen). Sedangkan jumlah penganggur karena dampak Covid-19 sebanyak 28,39 ribu orang atau sekitar 25,03 persen terhadap total penganggur (113,43 ribu orang) di NTB. Hasil dari perhitungan tersebut dilakukan secara kualitatif dengan mengacu pada tabel-tabel dan grafik selama kurun waktu 2018-2020.
\end{abstract}

Kata Kunci: Tingkat Pengangguran di Provinsi Nusa Tenggara Barat dan Covid 19

\begin{abstract}
This study aims to determine the increase in the unemployment rate due to Covid 19 in West Nusa Tenggara Province. This type of research is a descriptive method using secondary data which is analyzed using growth analysis at the unemployment rate. The results showed that of the 3.82 million working age population, there were 455.56 thousand people (11.93 percent) who were affected by Covid-19. Most of the working age population affected by Covid-19 experienced a reduction in working hours, namely 378.85 thousand people $(83.16$ percent). Meanwhile, the number of unemployed due to the impact of Covid-19 was 28.39 thousand people or around 25.03 percent of the total unemployed (113.43 thousand people) in NTB. The results of these calculations are carried out qualitatively by referring to tables and graphs during the period 2018-2020.
\end{abstract}

Keywords: Unemployment Rate in West Nusa Tenggara Province and Covid 19

\section{Pendahuluan}

Pembangunan ekonomi adalah sebuah proses multidimensi Pertumbuhan penduduk yang semakin meningkat dari tahun- ketahun mengakibatkan ketidakseimbangan antara pertumbuhan lapangan pekerjaan dengan bertambahnya tenaga kerja. Hal itu akan menimbulkan kelebihan penawaran tenaga kerja daripada permintaannya, sehingga memunculkan fenomena pengangguran. Di satu sisi, pengangguran menunjukkan adanya selisih antara permintaan (demand of labour) dan penawaran tenaga kerja (supply of labour) 
dalam suatu perekonomian. Sedangkan pertambahan penduduk yang semakin pesat dan semakin besar jumlahnya menyebabkan masalah pengangguran menjadi bertambah buruk (Budiarto,1985). Pandemi virus Covid-19 menyebabkan jumlah pengangguran bertambah khususnya di NTB. Sejak pandemi Covid-19, tak sedikit perusahaan-perusahaan yang menutup operasionalnya ada yang sementara, ada juga hingga batas waktu yang tak bisa ditentukan sehingga menyebabkan prakerja-prakerja akan menganggur untuk sementara waktu. Tutupnya sejumlah perusahaan hingga retail-retail besar seperti pusat perbelanjaan diprediksi akan menambah angka pengangguran sementara. Bahkan tak sedikit, perusahaan harus melakukan PHK pada karyawan-karyawannya. Banyaknya pekerja yang dirumahkan ataupun di PHK secara tak langsung memperlihatkan bahwa sebuah perusahaan mengalami krisis ekonomi. Lantaran, jumlah pemasukan selama Covid-19 menurun drastis.

Jumlah angkatan kerja pada Agustus 2020 sebanyak 2,69 juta orang, naik sekitar 81,77 ribu orang dibanding Agustus 2019. Sejalan dengan kondisi tersebut, Tingkat Partisipasi Angkatan Kerja (TPAK) juga meningkat sebesar 0,98 persen poin. Tingkat Pengangguran Terbuka (TPT) Agustus 2020 naik sebesar 0,94 persen poin menjadi 4,22 persen dibandingkan dengan Agustus 2019. Apabila dilihat menurut tingkat pendidikan, TPT tertinggi terdapat pada penduduk dengan pendidikan tamatan SMA Kejuruan, yaitu sebesar 9,71 persen. Pada Agustus 2020, penduduk yang bekerja sebanyak 2,58 juta orang, bertambah sekitar 53,84 ribu orang atau sebesar 2,13 persen. Persentase penduduk yang bekerja pada kegiatan informal meningkat sebesar 2,44 persen poin dibanding Agustus 2019. Selama setahun terakhir, 3 (tiga) lapangan pekerjaan yang mengalami peningkatan terbesar adalah penduduk yang bekerja di sektor pertanian, kehutanan dan perikanan (4,07 persen poin), perdagangan besar dan eceran; reparasi dan perawatan mobil (1,24 persen poin), dan penyediaan akomodasi dan makan minum (naik 0,45 persen poin). Pada Agustus 2020, terdapat 1,44 juta orang $(55,95$ persen) pekerja penuh atau penduduk yang bekerja dengan jam kerja minimal 35 jam per minggu. Sementara jumlah pekerja tidak penuh (jam kerja kurang dari 35 jam per minggu) sebanyak 1,13 juta orang (44,05 persen), terdiri dari 433,44 ribu orang setengah penganggur dan 701,24 ribu orang pekerja paruh waktu. Terdapat 455,56 ribu orang (11,93 persen) penduduk usia kerja yang terkena dampak Covid-19. Terdiri dari pengangguran karena Covid-19 (28,39 ribu orang), Bukan Angkatan Kerja (BAK) karena Covid-19 (12,66 ribu orang), sementara tidak bekerja karena Covid-19 (35,66 ribu orang), dan penduduk bekerja yang mengalami pengurangan jam kerja karena Covid-19 sebanyak 378,85 ribu orang. Berikut gambar grafik TPT berdasarkan pendidikan berdasarkan data dari Dinas Tenaga Kerja dan Transmigrasi. 


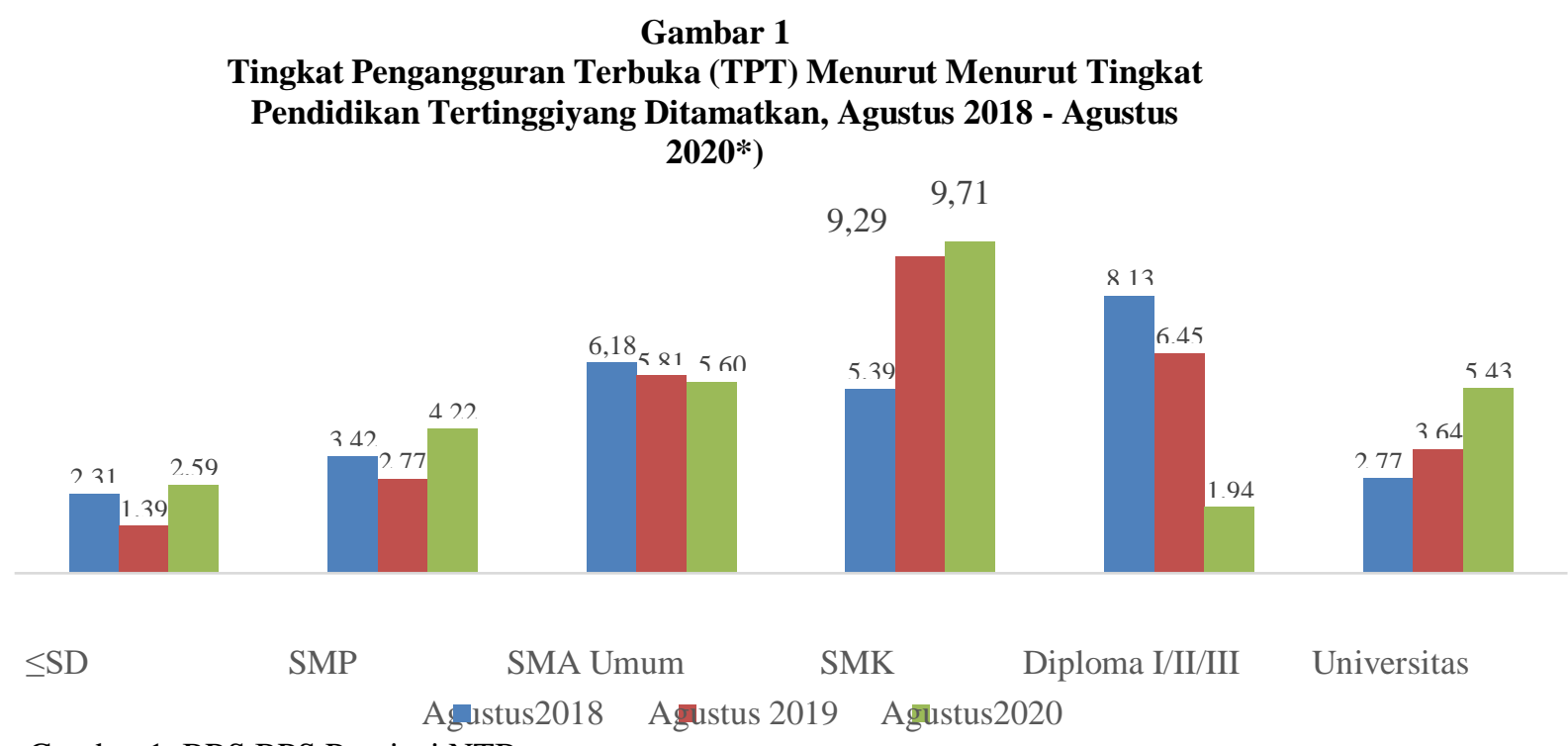

Gambar 1. BRS BPS Provinsi NTB

Covid-19 diketahui muncul pertama kali di Wuhan, China, pada Desember 2019. Tanggal 13 Januari 2020, terdapat kasus baru Covid-19 di luar China untuk pertama kalinya. Sedangkan di Indonesia, kasus pertama yang diumumkan Presiden adalah pada tangal 2 Maret 2020. Selanjutnya, Covid-19 dinyatakan sebagai pandemi oleh WHO pada tanggal 16 Maret 2020. Gubernur NTB sendiri mengumumkan penutupan bandara dan pelabuhan pada 24 April 2020. Sejak Covid-19 dinyatakan sebagai pandemi, Indonesia menerapkan Pembatasan Sosial Berskala Besar (PSBB) sampai dengan Mei 2020. Namun setelah itu, perlahan-lahan kegiatan ekonomi dan sosial mulai dibuka kembali pada Juni 2020.

Dengan adanya pandemi Covid-19, tidak hanya masalah kesehatan yang timbul, namun semua aspek dalam kehidupan ikut terdampak termasuk perekonomian. Perekonomian mulai menurun sejak diberlakukannya pembatasan aktivitas. Penurunan tersebut juga berdampak pada dinamika ketenagakerjaan di NTB. Tidak hanya pengangguran, penduduk usia kerja lainnya juga turut terdampak dengan adanya pandemi Covid-19.

Penduduk usia kerja yang terdampak Covid-19 tersebut dikelompokkan menjadi empat komponen yaitu a) Penganggur; b) Bukan angkatan kerja yang pernah berhenti bekerja pada Februari-Agustus 2020; c) Penduduk yang bekerja dengan status sementara tidak bekerja; dan d) Penduduk bekerja yang mengalami pengurangan jam kerja. Kondisi c) dan d) merupakan dampak pandemi Covid-19 yang dirasakan oleh mereka yang saat ini masih bekerja, sedangkan kondisi a) dan b) merupakan dampak pandemi Covid-19 bagi mereka yang berhenti bekerja.

Tabel 1 menunjukkan bahwa dari 3,82 juta penduduk usia kerja, terdapat 455,56 ribu orang (11,93 persen) yang terdampak Covid-19. Secara total, jumlah penduduk laki-laki yang terdampak Covid-19 lebih besar dibandingkan perempuan. Jika dilihat menurut daerah tempat tinggal, penduduk usia kerja yang berada di perkotaan yang terdampak Covid-19 lebih tinggi dibandingkan dengan penduduk usia kerja yang berada di wilayah perdesaan, yaitu 14,09 persen berbanding 9,80 persen. 
Tabel 1.

Dampak Covid-19 terhadap Penduduk Usia Kerja Menurut Jenis Kelamindan Tipe Wilayah, Agustus 2020

\begin{tabular}{|c|c|c|c|c|c|}
\hline \multirow[b]{2}{*}{$\begin{array}{l}\text { Komp } \\
\text { onen }\end{array}$} & \multicolumn{2}{|c|}{ Jenis Kelamin } & \multicolumn{2}{|c|}{ Tipe Wilayah } & \multirow[b]{2}{*}{$\begin{array}{l}\text { Total } \\
\text { (ribu } \\
\text { orang) }\end{array}$} \\
\hline & $\begin{array}{l}\text { Laki-laki } \\
\text { (ribu } \\
\text { orang) }\end{array}$ & $\begin{array}{l}\text { Perempuan } \\
\text { (ribu orang) }\end{array}$ & $\begin{array}{l}\text { Perkotaan } \\
\text { (ribu orang) }\end{array}$ & $\begin{array}{l}\text { Perdesaan } \\
\text { (ribu orang) }\end{array}$ & \\
\hline (1) & (2) & (3) & (4) & (5) & (6) \\
\hline Pengangguran karena Covid-192 & 16,73 & 11,66 & 19,35 & 9,04 & 28,39 \\
\hline $\begin{array}{l}\text { Bukan Angkatan Kerja (BAK) } \\
\text { karena } \\
\text { Covid-19 }\end{array}$ & 3,88 & 8,78 & 8,22 & 4,45 & 12,66 \\
\hline $\begin{array}{l}\text { Sementara Tidak Bekerja karena } \\
\text { Covid-19 }\end{array}$ & 19,53 & 16,13 & 21,66 & 14,00 & 35,66 \\
\hline $\begin{array}{l}\text { Penduduk Bekerja yang Mengalami } \\
\text { Pengurangan Jam Kerja karena } \\
\text { Covid-19 }\end{array}$ & 220,82 & 158,03 & 218,01 & 160,84 & 378,85 \\
\hline Total & 260,96 & 194,60 & 267,24 & 188,32 & 455,56 \\
\hline Penduduk Usia Kerja (PUK) & $1.853,52$ & $1.964,18$ & $1.896,29$ & $1.921,41$ & $3.817,70$ \\
\hline Persentase terhadap PUK & 14,08 & 9,91 & 14,09 & 9,80 & 11,93 \\
\hline
\end{tabular}

Keterangan:

1. Penghitungan dengan menggunakan penimbang SUPAS2015

2. Pengangguran karena Covid-19 adalah pengangguran yang berhenti bekerja karena Covid19 selama bulan Februari-Agustus 2020.3.Bukan Angkatan Kerja (BAK) karena Covid-19 adalah penduduk usia kerja yang termasuk dalam kategori bukan angkatan kerja dan pernah berhenti bekerja karena Covid-19 selama bulan Februari-Agustus 2020.

3. Tabel dari BRS BPS Provinsi NTB

Sebagian besar penduduk usia kerja yang terdampak Covid-19 mengalami pengurangan jam kerja, yaitu sebanyak 378,85 ribu orang (83,16 persen). Sedangkan jumlah penganggur karena dampak Covid-19 sebanyak 28,39 ribu orang atau sekitar 25,03 persen terhadap total penganggur (113,43 ribu orang) di NTB. Secara umum, pada semua kategori tersebut, jumlah laki-laki yang terdampak lebih banyak dibandingkan perempuan. Begitu juga jika dilihat menurut daerah tempat tinggal, penduduk usia kerja di daerah perkotaanlebih banyak terdampak Covid-19 dibandingkan dengan di perdesaan.

Gambar 2.

Distribusi Dampak Covid-19 Terhadap

Penduduk Usia KerjaMenurut Kelompok Umur, Agustus Agustus 2020

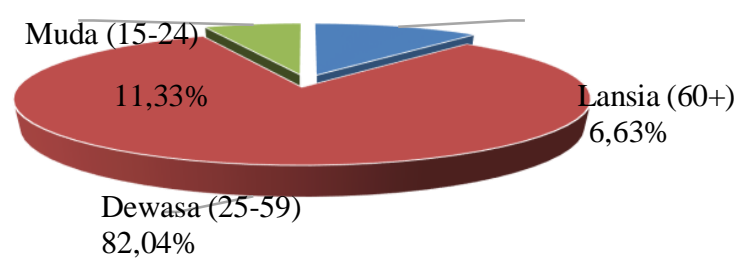


Apabila dilihat berdasarkan distribusi kelompok umur, kelompok umur dewasa (25-59 tahun) merupakan yang paling banyak terdampak Covid-19 yaitu sebanyak 373,72 ribu orang (82,04 persen), sedangkan pada kelompok umur muda (15-24 tahun) yang terdampak sebanyak 51,64 ribu orang (11,33 persen). Berbeda dengan kelompok umur muda, kelompok umur tua (60 tahun ke atas) hanya terdampak sebanyak 30,20 ribu orang atau sekitar 6,63 persen.

Berdasarkan uraian pada latar belakang di atas, bagaimana Perubahan tingkat pengangguran yang mengalami kenaikan akibat pandemi Covid-19 tersebut akan menjadi pijakan pemerintah daerah khususnya Provinsi NTB untuk menetapkan langkah-langkah kebijakan yang akan mengarah pada terciptanya pembangunan ekonomi yang lebih baik dalam menghadapi masa Covid-19 sehingga menjadi perhatian bagi pemerintah daerah dalam mencari solusi yang terbaik mengentaskan pengangguran .

\section{Tujuan dan Manfaat Penelitian}

Adapun tujuan penelitian ini adalah untuk mengetahui kenaikan tingkat pengangguran akibat Covid-19 di Provinsi NTB, sebagai informasi bagi pihak-pihak terkait dalam hal ini yang berkepentingan dengan proses pembangunan di Provinsi NTB.

\section{Kajian Pustaka Pengertian Pengangguran}

Pengangguran dalam pengertian makro ekonomi adalah sebagian dari angkatan kerja yang sedang tidak mempunyai pekerjaan, Pengangguran merupakan suatu keadaan di mana seseorang yang tergolong dalam angkatan kerja ingin mendapatkan pekerjaan tetapi mereka belum dapat memperoleh pekerjaan tersebut (Sukirno, 1994).Dalam pengertian mikro pengangguran adalah keadaan seorang yang mampu dan mau melakukan pekerjaan akan tetapi sedang tidak mempunyai pekerjaan (Suroto, 1992). Pengangguran merupakan suatu fenomena yang terjadi di semua Negara berkembang tidak terkecuali di Indonesia. Pengangguran adalah suatu keadaan dimana seseorang yang tergolong dalam angkatan kerja tidak memiliki pekerjaan dan secara aktif sedang mencari pekerjaan. Pengangguran meliputi penduduk yang sedang mencari pekerjaan, atau mempersiapkan suatu usaha, atau merasa tidak mungkin mendapatkan pekerjaan, atau sudah punya pekerjaan tetapi belum mulai bekerja (Muana, 2001; BPS,2016). Pengangguran pada prinsipnya mengandung arti hilangnya output (loss of output) dan kesengsaraan bagi orang yang tidak bekerja (human misery) dan merupakan suatu bentuk pemborosan sumber daya ekonomi (Nanga, 2001). Orang yang tidak mau bekerja tidak dapat dikatakan sebagai pengangguran, sebab jika ia mencari pekerjaan (ingin bekerja) mungkin dengan segera mendapatkannya. Sebab definisi ekonomi tenta ng pengangguran tidak identik dengan tidak (mau) bekerja. Seseorang baru dikatakan menganggur bila dia ingin bekerja dan telah berusaha mencari kerja, namun tidak mendapatkannya (Rahardja, 2004).

Soeroto (1992) membedakan definisi penganggur dan pengangguran. enganggur adalah orang yang mampu bekerja, tidak mempunyai pekerjaan, dan ingin bekerja atau baik secara aktif, maupun pasti mencari pekerjaan. Dia adalah anggota angkatan kerja yang tidak mempunyai 
pekerjaan. Sedangkan pengangguran adalah kejadiaan atau keadaan orang yang sedang menganggur. Pengangguran tidak sama dengan tidak bekerja atau tidak mau bekerja. Penganggur adalah mereka yang segang mencari pekerjaan, atau mereka yang mempersiapkan usaha, atau mereka yang tidak mencari pekerjaan karena merasa tidak mungkin mendapatkan pekerjaan (sebelumnya dikatagorikan sebagai bukan angkatan kerja), dan mereka yang sudah punya pekerjaan tetapi belum mulai bekerja (sebelumnya dikatagorikan sebagai pekerja), dan pada waktu yang bersamaanmereka tidak bekerja (jobless). Penganggur dengan konsep/definisi tersebut biasanya disebut sebagai penganggur terbuka atau Open unemployment (Kuncoro, 2013). Dalam penelitiannya Prihanto (2012) menyatakan masalah pengangguran terbuka dan berpendidikan akan berdampak pada merosotnya daya beli masyarakat, serta menurunnya produktivitas masyarakat. Selain itu, meningkatnya pengangguran dapat mempengaruhi kondisi sosial dan politik yang serius, seperti meningkatnya kriminalitas dan gangguan terhadap stabilitas politik negara.

Badan Pusat Statistiik mendefinisikan penganggur adalah penduduk yang tidak bekerja tetapi berharap mendapat pekerjaan, dan kegiatannya terdiri dari encari pekerjaan, mempersiapkan usaha, tidak mencari pekerjaan karena alasan merasa tidak mungkin mendapatkan pekerjaan (putus asa), tidak mencari pekerjaan karena sudah mempunyai pekerjaan tetapi belum mula bekerja. Mankiw, dkk (2008) mengatakan bahwa seseroang dikatgorikan bekerja jika ia menghabiskan beberapa hari pada minggu sebelumnya untuk mengerjakan pekerjaan yang dibayar. Kemudian seseoran dianggap pengangguran jika ia berhenti bekerja semetara atau sedang mencari pekerjaan. Mulyadi (2012) mengatakan Tingkat pengangguran (Unemployment) adalah angka yang menunjukkan berapa banyak dan jumlah angkatan kerja yang sedang aktif mencari pekerjaan. Pengertian menganggur disini adalah aktif mencari pekerjaan. Sedang Pengangguran terbuka (Open Unemployment) atau pengangguran adalah bagian dari angkatan kerja yang sekarang ini tidak bekerja dan sedang aktif mencari pekerjaan.

$$
T P=\frac{\text { Jumlah erang yang mencart pekerjaan }}{\text { Jumlah angkatan kerja }} \times 100 \%
$$

Berdasarkan beberapa pengertian dari pengangguran dalam tulisan ini adalah konsep/definisi dan formulasi yang berasal dari Badan Pusat Statistik.

\section{Metode Penelitian \\ Jenis Penelitian yang Dipergunakan}

Jenis Penelitian yang dipergunakan adakan metode deksriptif, metode penelitian deskriptif merupakan penelitian naratif yang digunakan dalam desain riset kualitatif atau kualitatif. Metode penelitian yang proses pengumpulan datanya memungkinkan peneliti untuk menghasilkan deskripsi tentang fenomena sosial yang diteliti. Melalui data deskriptif, peneliti mampu mengidentifikasi mengapa, apa dan bagaimana fenomena sosial terjadi. Sebagaimana yang sudah diungkap diawal, tujuan utama metode penelitian deskriptif ada tiga: mendeskripsikan, menjelaskan, dan memvalidasi temuan penelitian. Peneliti mencapai tujuan tersebut setelah mendeskripsikan karakteristik atau perilaku individu atau kelompok sosial yang diteliti. Dalam penelitian ini yang ingin diteliti adalah tingkat pengangguran yang mengalami 
peningkatan berdasarkan data dari BPS, yang terjadi akibat pandemi Covid 19 di Provinsi Nusa Tenggara Barat pada priode waktu 2018-2020.

\section{Lokasi Penelitian dan Metode Penelitian}

Penelitian ini mengambil data tingkat pengangguran yang ada di Provinsi Nusa Tenggara Barat. Alasan yang mendasarinya karena ingin mengetahui tingkat pengangguran yang diakibatkan oleh pandemi Covid 19 di Provinsi Nusa Tenggara Barat yang mengalami peningkatan yang cukup cepat terutama dilihat dari bertambahnya jumlah pekerja yang mengalami pemutusan kerja. Dampak Covid 19 bagi sektor ekonomi khususnya di NTB sangat besar, bertambahnya jumlah pengangguran mengakibatkan perubahan jumlah penduduk miskin di NTB menjadi bertambah sehingga menjadi perhatian khusus bagi pihak-pihak terkait untuk bagaimana merumuskan kebijakan-kebijakan dalam mengentaskan jumlah pengangguran.

\section{Data Yang Dipergunakan}

Penelitian ini menggunakan data sekunder. Data sekunder merupakan berbagai informasi yang telah ada sebelumnya dan dengan sengaja dikumpulkan oleh peneliti yang digunakan untuk melengkapi kebutuhan data penelitian. Data sekunder diperoleh dari berbagai instansi yang berkaitan langsung dengan penelitian ini. Jenis data yang dibutuhkan adalah data yang berkaitan dengan tingkat pengangguran yang terjadi akibat Covid 19 di Provinsi Nusa Tenggara Barat dari tahun 2019-2020.

\section{Analisis Data}

Data kuantittatif yang diperoleh dianalisis dengan mempergunakan analisis pertumbuhan pada tingkat pengangguran menggunakan formulasi yang telah diuraikan pada tinjauan pustaka. Hasil dari perhitungan tersebut dilakukan secara kualitatif dengan mengacu pada tabel-tabel dan grafik selama kurun waktu 2018-2020.

\section{Hasil Dan Pembahasan}

Tabel 2.

Jumlah Penduduk Usia Kerja menurut Jenis Kegiatan Seminggu Yang Lalu, Tingkat PengangguranTerbuka (TPT) dan Tingkat Partisipasi Angkatan Kerja (TPAK) di Provinsi Nusa Tenggara Barat, Agustus 2020

\begin{tabular}{|c|c|c|c|c|c|c|}
\hline \multirow[b]{2}{*}{ Kabupaten/Kota } & \multicolumn{4}{|c|}{ Jenis kegiatan (ribu orang) } & \multirow[b]{2}{*}{$\begin{array}{c}\text { TPT } \\
\text { (persen) }\end{array}$} & \multirow[b]{2}{*}{$\begin{array}{l}\text { TPAK } \\
\text { (persen) }\end{array}$} \\
\hline & Bekerja & $\begin{array}{l}\text { Pengang- } \\
\text { guran }\end{array}$ & $\begin{array}{c}\text { Bukan } \\
\text { Angkatan } \\
\text { Kerja }\end{array}$ & Total & & \\
\hline 5201 Lombok Barat & 342,53 & 16,44 & 169,79 & 528,77 & 4,58 & 67,89 \\
\hline
\end{tabular}




\begin{tabular}{|l|r|r|r|r|r|r|}
\hline 5202 Lombok Tengah & 518,56 & 20,17 & 179,21 & 717,93 & 3,74 & 75,04 \\
\hline 5203 Lombok Timur & 582,81 & 25,38 & 284,77 & 892,96 & 4,17 & 68,11 \\
\hline 5204 Sumbawa & 230,51 & 9,63 & 107,33 & 347,47 & 4,01 & 69,11 \\
\hline 5205 Dompu & 121,61 & 4,13 & 53,75 & 179,49 & 3,28 & 70,06 \\
\hline 5206 Bima & 248,45 & 7,40 & 98,18 & 354,02 & 2,89 & 72,27 \\
\hline 5207 Sumbawa Barat & 74,26 & 4,32 & 34,12 & 112,70 & 5,50 & 69,73 \\
\hline 5208 Lombok Utara & 117,48 & 3,65 & 43,45 & 164,58 & 3,01 & 73,60 \\
\hline 5271 Mataram & 244,77 & 17,93 & 123,25 & 385,94 & 6,83 & 68,07 \\
\hline 5272 Kota Bima & 94,97 & 4,39 & 34,48 & 133,84 & 4,42 & 74,24 \\
\hline NTB & $2.575,96$ & 113,43 & $1.128,31$ & $3.817,70$ & 4,22 & 70,45 \\
\hline
\end{tabular}

Tabel 2. dari BRS BPS Provinsi NTB

1. Penduduk usia kerja adalah penduduk berumur 15 tahun ke atas.

2. Angkatan kerja adalah penduduk usia kerja yang bekerja (termasuk yang punya pekerjaan namun sementara tidak bekerja) dan pengangguran. Bukan Angkatan Kerja adalah penduduk usia kerja yang kegiatan utamanya sekolah, mengurus rumah tangga atau melaksanakan kegiatan lainnya selain kegiatan pribadi.

3. Bekerja adalah kegiatan ekonomi yang dilakukan seseorang dengan maksud memperoleh atau membantu memperoleh penghasilan atau keuntungan paling sedikit selama satu jam dalam seminggu yang lalu. Bekerja selama satu jam tersebut harus dilakukan berturut-turut dan tidak terputus. Kegiatan tersebut termasuk pula kegiatan pekerja tak dibayar yang membantu dalam suatu usaha/kegiatan ekonomi.

4. Penganggur adalah penduduk yang tidak bekerja tetapi berharap mendapat pekerjaan, dan kegiatannya terdiri dari: Mencari pekerjaan, Mempersiapkan usaha, Tidak mencari pekerjaan karena alasan merasa tidak mungkin mendapatkan pekerjaan (putus asa), Tidak mencari pekerjaan karena sudah mempunyai pekerjaan tetapi belum mulai bekerja.

5. Tingkat Partisipasi Angkatan Kerja (TPAK) adalah rasio jumlah angkatan kerja terhadap jumlah penduduk usia kerja. Tingkat Pengangguran Terbuka (TPT) adalah rasio jumlah penganggur terbuka terhadap jumlah angkatan kerja.

6. Penduduk yang bekerja pada sektor informal adalah penduduk bekerja yang berstatus berusaha sendiri, berusaha dibantu buruh tidak tetap/buruh tidak dibayar, pekerja bebas, dan pekerja keluarga. Sedangkan penduduk yang bekerja pada sektor formal adalah penduduk berstatus berusaha dibantu buruh tetap/buruh dibayar dan buruh/karyawan/pegawai.

7. Pekerja penuh adalah penduduk yang bekerja dengan jam kerja 35 jam atau lebih dalam seminggu, dan termasuk mereka yang kondisinya sementara tidak bekerja. Sedangkan pekerja tidak penuh adalah mereka yang bekerja kurang dari 35 jam seminggu, dan terdiri 
dari pekerja setengah penganggur dan pekerja paruh waktu.

8. Setengah Penganggur adalah mereka yang bekerja kurang dari 35 jam seminggu dan masih mencari pekerjaan atau masih bersedia menerima pekerjaan (dahulu disebut setengah pengangguran terpaksa); Pekerja paruh waktu adalah mereka yang bekerja kurang dari 35 jam seminggu tetapi tidak mencari pekerjaan atau tidak bersedia menerima pekerjaan lain (dahulu disebut setengah pengangguran sukarela).

9. Upah/gaji sebulan adalah imbalan/balas jasa yang diterima selama sebulan yang lalu dari pekerjaan utama oleh buruh/karyawan/pegawai, baik berupa uang maupun barang yang dibayarkan oleh perusahaan/kantor/majikan. Imbalan/balas jasa tersebut terdiri dari beberapa komponen yaitu gaji, tunjangan (yang sifatnya rutin), upah lembur, uang transportasi dan uang makan.

10. Buruh/karyawan/pegawai adalah seseorang yang bekerja pada orang lain atau instansi/kantor/perusahaan secara tetap dengan menerima upah/gaji baik berupa uang maupun barang. Buruh/karyawan/pegawai yang tidak mempunyai majikan tetap, tidak digolongkan sebagai buruh/karyawan/pegawai, tetapi sebagai pekerja bebas. Seseorang dianggap memiliki majikan tetap jika memiliki 1 (satu) majikan yang sama dalam sebulan terakhir. Khusus pada sektor konstruksi batasannya tiga bulan. Apabila majikannya instansi/lembaga, boleh lebih dari satu.

\section{Kesimpulan Dan Saran}

\section{Kesimpulan}

Berdasarkan analisis di atas, dapat ditarikbeberapa kesimpulan sebagai berikut :

1. Dari 3,82 juta penduduk usia kerja, terdapat 455,56 ribu orang (11,93 persen) yang terdampak Covid-19. Secara total, jumlah penduduk laki-laki yang terdampak Covid-19 lebih besar dibandingkan perempuan. Jika dilihat menurut daerah tempat tinggal, penduduk usia kerja yang berada di perkotaan yang terdampak Covid-19 lebih tinggi dibandingkan dengan penduduk usia kerja yang berada di wilayah perdesaan, yaitu 14,09 persen berbanding 9,80 persen. Hal ini berarti setiap kepala keluarga yang bekerja dan berada di wilayah perkotaan sangat rentan terkena dampak pemutusan kerja akibat Covid19 sehingga bertambahnya jumlah pengangguran.

2. Sebagian besar penduduk usia kerja yang terdampak Covid-19 mengalami pengurangan jam kerja, yaitu sebanyak 378,85 ribu orang (83,16 persen). Sedangkan jumlah penganggur karena dampak Covid-19 sebanyak 28,39 ribu orang atau sekitar 25,03 persen terhadap total penganggur (113,43 ribu orang) di NTB. Kondisi ini menjadi indikasi yang sangat besar akibat pandemi Covid-19, dan menjadi perhatian yang serius oleh pihak terkait dengan pertambahan tingkat pengangguran.

3. Apabila dilihat berdasarkan distribusi kelompok umur, kelompok umur dewasa (25-59 tahun) merupakan yang paling banyak terdampak Covid-19 yaitu sebanyak 373,72 ribu orang (82,04 persen), sedangkan pada kelompok umur muda (15-24 tahun) yang terdampak sebanyak 51,64 ribu orang (11,33 persen). Berbeda dengan kelompok umur 
muda, kelompok umur tua (60 tahun ke atas) hanya terdampak sebanyak 30,20 ribu orang atau sekitar 6,63 persen. Artinya harus ada perlindungan bagi kelompok umur dewasa yang terdampak Covid-19, sehingga tidak menjadi penduduk miskin baru.

\section{Saran}

1. Pemerintah Provinsi Nusa Tenggara Barat harus merumuskan strategi yang terbaik dalam menghadapi Covid-19 khususnya sektor ekonomi sehingga dampak dari pandemi Covid19 tidak menimbulkan masalah baru terutama pengangguran. Pemerintah Provinsi Nusa Tenggara Barat terus melakccukan kebijakan- kebijakan yang mengarah pada terciptanya kesempatan kerja baru dengan memberikan peluang seluas- luasnya kepada sektor Usaha Kecil Menengah baik formal maupun informal sehingga dapat memberikan kesempatan kerja baru bagi penduduk yang masih tergolong menganggur. Karena semkin tinggi angka pengangguran maka semakin tinggi pula angka kemiskinan yang terjadi

2. Program-program yang merupakan subsidi bagi yang terdampak Covid-19 harus tepat sasaran dan dirasakan manfaatnya, terutama bagi yang tidak memiliki pekerjaan.

\section{Daftar Pustaka}

Arsyad, Lincolin. 2010. Ekonomi Pembangunan. Edisi 5. Yogyakarta, UPP STIM YKPN.

Badan Pusat Statistik Provinsi Nusa Tenggara Barat. Berita Resmi Statistik ; Profil Pengangguran Di Nusa Tenggara Barat Maret dan September 2018 -2020, Mataram.

Badan Pusat Statistik Provinsi Nusa Tenggara Barat. Berita Resmi Statistik; Keadaan Ketenagakerjaan Di Nusa Tenggara Barat Peberuari dan September 2018-2020, Mataram.

Budiarto dan Munir, 1985. Teknik Analisa Kependudukan. Rineka Cipta. Jakarta.

Huda, Nurul. Dkk. 2015. Ekonomi Pembangunan Islam. Jakarta. PT. PranadaMedia Group.

Kuncoro, Mudrajat. 2013. Mudah Memahami dan Menganalisis Indikator Ekonomi. Yogyakarta,UPP STIM YKPN.

Maipita, Indra. 2014. Mengukur Kemiskinan dan Distribusi Pendapatan. Yogyakarta. UPP STIM YKPN.

Mankiw, N. Gregory. Euston Quah dan Peter Wilson. 2013. Pengantar Ekonomi Makro. Jakarta, Salemba Empat.

Mulyadi, S. 2012. Ekonomi Sumber Daya Manusia Dalam Perspektif Pembangunan. Jakarta. PT. RadjaGrafindo Persada.

Nanga, Muana. 2001. Makro Ekonomi Teori Masalah dan Kebijakan. Edisi Perdana. Jakarta. PT RadjaGrafindo Persada.

Pangiuk, Ambok. 2018. Pengaruh Pertumbuhan Ekonomi Terhadap Penurunan Kemiskinan Di Provinsi Jambi Tahun 2009 - 2013. Iltizam Journal Of Syariah Economics Research. Volume 2. No. 2, 2018.

Pemerintah Provinsi Nusa Tenggara Barat. 2019. Rencana Pembangunan Jangka Menengah 
(RPJMD) Provinsi Nusa Tenggara Barat Tahun 2019 - 2013., Mataram.

Pressman, Steven, 2000. Lima Puluh Pemikir Ekonomi Dunia. Jakarta; Murai Kencana PT RadjaGrafindo Persada.

Rahardja, Pratama dan Mandala Manurung. 2001. Teori Ekonomi Makro Suatu Pengantar. Jakarta, Lembaga Penerbit Fakultas Ekonomi dan Universitas Indonesi(LPFE-UI).

Subandi. 2019. Ekonomi Pembangunan. Bandun, Alfabeta.

Sumarsono, Sony. 2009. Teori dan Kebijakan Publik. Ekonomi Sumber Daya Manusia. Yogyakarta, Graha Ilmu.

Sun'an, Muammil dan Abdurrahman Senuk. 2015. Ekonomi Pembangunan Daerah. Jakarta. Mitra Wacana Media.

Suroto, 1993. Strategi Pembangunan dan Perencanaan Kesempatan Kerja, Yogyakarta, Gadjah Mada Univesity Press.

Suwandika, Putu Eka dan I Nyoman Mahendra Yasa. 2015. Pengaruh Pendapatan Asli Daerah Dan Investasi Terhadap Pertumbuhan Ekonomi dan Tingkat Pengangguran di Provinsi Bali. E-Jurnal Ekonomi Pembangunan Universitas Udayana Vol 4. No. 7 Juli2015.

Yasin, Muaidy dkk. 2020. Analisis Pertumbuhan Ekonomi, Pengangguran Dan Kemiskinan Di Kabupaten Lombok Tengah. E-Jurnal EKONOBIS Universitas Mataram Volume 6, No.2 September 2020 
REKAN

Riset Ekonomi, Akeuntansi dan Perpajakan
Vol 2 No. 1 Maret 2021

e-ISSN : 2721-4109

DOI: 10.30812/rekan.v2i1.1116 